\title{
Makings of a French Science Policy
}

FUTURE French science policy is outlined in the pages of La Recherche this week where the leaders of the chief political parties outline their views on science in France in preparation for the general election in March. If election promises are kept, the outlook for science is none too bright.

M. Jean Charbonnel, minister for industrial and scientific development, seems fairly happy with the status quo. The organization of French science is more than adequate he says, and the existing problems are simply administrative ones. Medium and small companies must be encouraged to undertake research, even though the 1973 budget has produced a cut in the sixth five-year plan (see Nature, 240, 64; 1972). By the end of the plan (1977) he hopes that the growth rate in science will be back on course, and he points out eagerly that the grands programmes of space, computing and nuclear power have been kept viable in spite of budget cuts.

Discussing European problems, M. Charbonnel reaffirms France's desire to see a European space policy, pointing out that if the proposal for the L3S launcher (put to the European Space Conference on December 20) goes through, the project will be centred around French industry and technology, demonstrating the quality of French skills.

Nonetheless M. Charbonnel singles out research on the quality of life as the most important area for study.

The views of the left-wing allianceunion of the communist and socialist parties-are represented only by the opinions of Roland Leroy, secretary of the central committee of the French Communist Party, as M. Francois Mitterand, the national secretary of the Socialist Party withdrew his replies to La Recherche's questions at the last moment. This withdrawal will only feed the fears of those who believe that French politicians are largely uninterested in science policy, and the fact that the leftist alliance may well gain seats in the forthcoming election presents, to many scientists in France, a worrying prospect if Mitterand's actions reffect his interest.

Leroy maintains that, given power, he would completely reverse French science policy, at the same time increasing expenditure on science to 3 per cent of the gross national product. Numbers of French scientists should be increased and most should work in the public research organizations, while greater efforts should be made for European cooperation. Leroy would also put an end to work on France's atomic bomb, directing the work of the Commissariat à l'Energie Atomique, which he would expand, to more peaceful ends. Leroy, too, would encourage work designed to improve social, working and living conditions.

Michel Poniatowski, secretary general of the Federation of Independent Republicans, and as such a member of the majority, agrees that politicians tend not to be interested in science and blames this on the failure of scientists and civil scrvants to involve the public in science. He is heavily critical of the way the science plan is developed over a five-month period each year without any knowledge of the final budget within which it will have to operate.

Poniatowski also argues that fundamental science is already well financed, but urges that applied science should receive more attention, particularly in the universities.

The French space programme receives some caustic criticism, M. Poniatowski warning that France must not go ahead alone with a policy that is beyond the limits of its resources. On the other hand oceanography should receive more

\section{SELECT COMMITTEE}

\section{Reuctor Sufely Queried}

THE Select Committee on Science and Technology is becoming increasingly concerned about the safety of nuclear reactors, particularly in the light of rumours that the government is to buy light water reactors from the USA.

The committee's concern is underlined by the decision to have a special showing in the next few days of last week's World in Action programme on the United States nuclear industry which brought allegations that the light water reactors are not as safe as they might be to the fore again.

This week, however, the committee was assured of the safety of the British steam generating heavy water reactor (SGHWR) by Mr S. A. Ghalib, managing director of The Nuclear Power Group (TNGP), when the group gave evidence to the committee The select committee has long favoured the SGHWR and is eager to see it built for the Central Electricity Generating Board, and TNPG made it clear that it is equally enthusiastic. Mr Ghalib said attention. Poniatowski would also work to see research scientists and their views included in government deliberations.

Michel Rocard, national secretary of the United Socialist Party, argues that since M. Pompidou came to power there has been no research policy, and he is highly critical of the way American nuclear power companies have been allowed to overtake French expertise. The money poured into the CEA for twenty-five years, he says, has been to no purpose.

The liveliest selection of views offered by the political leaders are those of Jean-Jacques Servan-Schreiber, although his chances of putting them into effect are slim. Science for him is a sacred cow. There is a "plethora of research scientists", he complains; the numbers working for CNRS should be cut, their expertise being distributed among the universities, technical colleges and industry. Only the best qualified research scientists should work in public organizations, and as much as one-fifth of the science budget should be poured into private industry. Much more research should be run on the American contract basis, he says, and the bureaucracy involved in running science at present should be heavily cut down.

that there is no doubt that the SGHWR is safer than either the pressurised water reactors or the boiling water reactors. Operating experience of the $1 \mathrm{MW}$ prototype at Winfrith and the fact that SGHWR is built on already proven technologies combine, he said, to make development risks minimal.

The group welcomed the proposed merger of the two existing consortia, urging that the new company be made up of three components-themselves, British Nuclear Design and Construction and British Nuclear Fuels. The sooner the reorganization takes place the better according to Sir Edwin McAlpine, TNPG's chairman. Sir Edwin also made it clear that once the reorganization is complete, plans can begin for the formation of an allEuropean nuclear company, probably the result of an amalgamation of the new British company and Kraftwerk Union of Western Germany. This company, Sir Edward said, would, in time, probably be the only all-European company operating in Europe, although competition could be expected from Westinghouse and GEC subsidiaries. 